\title{
Optimization of an Ultrasound-Assisted Extraction Method for the Analysis of Major Anthocyanin Content in Erica australis Flowers
}

\author{
Ceferino Carrera ${ }^{1}{ }^{\oplus}$, María José Aliaño-González ${ }^{1}{ }^{\complement}$, Jaime Rodríguez-López ${ }^{2}$, Marta Ferreiro-González ${ }^{1}{ }^{\circledR}$, \\ Fernando Ojeda-Copete ${ }^{2}\left(\mathbb{D}\right.$, Gerardo F. Barbero ${ }^{1, *(1)}$ and Miguel Palma ${ }^{1} \mathbb{D}$
}

1 Department of Analytical Chemistry, Faculty of Sciences, Agrifood Campus of International Excellence (ceiA3), IVAGRO, University of Cadiz, Puerto Real, 11510 Cadiz, Spain; ceferino.carrera@uca.es (C.C.); mariajose.alianogonzalez@alum.uca.es (M.J.A.-G.); marta.ferreiro@uca.es (M.F.-G.); miguel.palma@uca.es (M.P.)

2 Department of Biology, Faculty of Marine and Environmental Sciences, University of Cadiz, Puerto Real, 11510 Cadiz, Spain; jaime.rodriguezlopez@alum.uca.es (J.R.-L.); fernando.ojeda@uca.es (F.O.-C.)

* Correspondence: gerardo.fernandez@uca.es; Tel.: +34-956-016355; Fax: +34-956-016460

check for updates

Citation: Carrera, C.;

Aliaño-González, M.J.;

Rodríguez-López, J.;

Ferreiro-González, M.; Ojeda-Copete,

F.; Barbero, G.F.; Palma, M.

Optimization of an

Ultrasound-Assisted Extraction

Method for the Analysis of Major Anthocyanin Content in Erica australis Flowers. Molecules 2021, 26, 2884. https://doi.org/10.3390/molecules 26102884

Academic Editor: Ana Fernandes

Received: 15 April 2021

Accepted: 11 May 2021

Published: 13 May 2021

Publisher's Note: MDPI stays neutral with regard to jurisdictional claims in published maps and institutional affiliations.

Copyright: (C) 2021 by the authors. Licensee MDPI, Basel, Switzerland. This article is an open access article distributed under the terms and conditions of the Creative Commons Attribution (CC BY) license (https:// creativecommons.org/licenses/by/ $4.0 /)$.

\begin{abstract}
Erica australis plants have been used in infusions and folk medicine for years for its diuretic and antiseptic properties and even for the treatment of infections. In addition, a recently published thorough study on this species has demonstrated its antioxidant, antibiotic, anti-inflammatory, anticarcinogenic and even antitumoral activities. These properties have been associated with the high content of anthocyanins in E. australis leaves and flowers. The aim of the present research is to optimize an ultrasound-assisted extraction methodology for the recovery of the anthocyanins present in E. australis flowers. For that purpose, a Box Behnken design with response surface methodology was employed, and the influence of four variables at different values was determined: namely, the composition of the extraction solvents $(0-50 \% \mathrm{MeOH}$ in water), the $\mathrm{pH}$ level of those solvents (3-7), the extraction temperature $\left(10-70{ }^{\circ} \mathrm{C}\right)$, and the sample:solvent ratio $(0.5 \mathrm{~g}: 10 \mathrm{~mL}-0.5 \mathrm{~g}: 20 \mathrm{~mL})$. UHPLC-UV-vis has been employed to quantify the two major anthocyanins detected in the samples. The extraction optimum conditions for $0.5 \mathrm{~g}$ samples were: $20 \mathrm{~mL}$ of solvent $\left(50 \% \mathrm{MeOH}: \mathrm{H}_{2} \mathrm{O}\right)$ at $5 \mathrm{pH}$, with a $15 \mathrm{~min}$ extraction time at $70^{\circ} \mathrm{C}$. A precision study was performed and the intra-day and inter-day relative standard deviations (RSDs) obtained were $3.31 \%$ and $3.52 \%$, respectively. The developed methodology has been successfully applied to other Erica species to validate the suitability of the method for anthocyanin extraction.
\end{abstract}

Keywords: flower anthocyanins; Mediterranean heather; ultrasound-assisted extraction; optimization; Box-Behnken design; HPLC-UV-vis

\section{Introduction}

The Mediterranean heather Erica australis L. is a medium-sized, evergreen shrub of the Ericaceae family. Plants in this species can reach up to $2 \mathrm{~m}$ high with profuse flowering of distinctive $6.0-8.5 \mathrm{~mm}$ long, pink to rose-purple flowers. They can be mainly found in Mediterranean heathlands of the W Iberian Peninsula and NW tip of Africa [1,2].

This species readily recovers from fire, both by the resprouting of surviving plants and by seedling recruitment from a permanent soil seed-bank [3-5]. For this reason, their use in areas which have recently suffered the effects of wildfire or that are prone to suffer such effects has notably increased [4]. On the other hand, E. australis has been extensively used as infusions, especially in Moroccan and Turkish folk medicine because of their demonstrated diuretic and antiseptic properties, and even to directly treat infected wounds [6,7].

This growing number of applications has increased the interest of multiple researchers for the plant composition and how it influences its applications. Some extracts from this plant have exhibited important health promoting properties such as antioxidant, antibiotic, 
anti-inflammatory, anticarcinogenic and antitumoral [8]. In addition, it has also been proven that it can increase the metabolic activity in the fibroblast proliferation that is closely related to tissue regeneration [9]. These are the reasons why they have been used for the treatment of different diseases, including tumoral processes [10], prostate, kidney or bladder disorders [11], or even for the treatment of hyperlipidemia, which has an important impact on cardiovascular pathologies [12]. In addition, its use in the cosmetic industry has also grown considerably because of its antioxidant activity as well as for its color and other physical properties [13]. Finally, its flowers are also and increasingly being used in the agri-food industry as an accompaniment in multiple gourmet plates. The consumption of $E$. australis flowers as part of our diet is meant to promote significant health benefits.

An in depth study on the composition of E. australis has demonstrated its substantial concentrations of amino acids and phenolic compounds and, particularly, of anthocyanins, which are responsible for many of the biological properties of this plant, and can be found in greater concentrations in its leaves and flowers [14-16]. Anthocyanins are a subcategory of phenolic compounds $[17,18]$ that act as natural pigments to provide different vegetables and fruits such as sloes, myrtle, maqui berry, açai, blueberry, Camellia sinensis flowers, Primula veris, etc. with their characteristic red or blue color [19-24]. These compounds have been associated with specific health promoting properties like antioxidant, anti-inflammatory, anticarcinogenic, or with beneficial effects on the treatment of obesity, microcirculation, cardiovascular or neurodegenerative disorders [25-28]. In addition, they have exhibited important vasodilatation capacity with pain relief effects. For all these reasons, relying on efficient methodologies for the extraction and analysis of anthocyanins from E. australis, while allowing their analysis and control, would be really important for decisive medical, cosmetic, pharmaceutical applications, and even for their use in the food industry as a natural colorant.

Even though the benefits and properties of E. australis have been extensively confirmed, there are scarce research studies investigating in depth the use of innovative extraction techniques for the analysis of anthocyanins in Erica plants, being solid-liquid, microwave hydrodiffusion and gravity extractions the most frequently used methods $[8,9,12,13]$. Ultrasound-assisted extraction (UAE) is a technique based on the phenomenon of cavitation caused by the ultrasound energy and its mechanical effect on the plant matrix, which favors the mass transfer from the sample into the solvent, thus achieving an efficient extraction of the desirable compounds from different matrices [29]. In addition, the application of high temperatures increases the number and size of the bubbles that are generated by the cavitation phenomenon and further improve the efficiency of the extraction method in most cases [30].

UAE represents an important improvement with respect to other extraction techniques, since it is easy-to-use, economical, rapid and only requires low amounts of solvents. Other extraction techniques (pressure liquid extraction (PLE) or supercritical fluid extraction (SFE)) have some of these advantages such as speed in extraction or low consumption of solvents, but they are more expensive techniques and with less availability in most analytical laboratories [31,32]. Furthermore, it does not require any complex maintenance operations and has been extensively used all over the world, which means that we are all quite familiarized with its characteristics and application methods [33]. In conclusion, UAE employs simple and relatively cheap instrumentation, presents low energy consumption, the time of analysis is quite short, does not require the application of pressure, and high temperatures are not needed. Furthermore, the phenomenon of cavitation produced by the effect of ultrasound in the extracting medium, favors cell rupture and the transmission of the analytes of interest within the solution. In fact, it has already been used for the extraction of anthocyanins from numerous matrices such as onion (Allium cepa), lavender (Lavandula spp.), blackberries (Rubus spp.), pepper (Capsicum spp.), açai (Euterpe oleracea), purple potato (Solanum tuberosum), blackthorn (Prunus spinosa), breadnut (Brosimum alicastrum), etc. [34-42].

Multiple methodologies have been employed for the separation and quantification of anthocyanins in food matrixes as liquid chromatography with ultraviolet/visible detection 
or liquid chromatography-mass spectrometry (LC-UV-vis and LC-MS) [24,43]. However, the technique most used for the analysis of anthocyanins in the Erica genus has been highperformance liquid chromatography with diode-array detection (HPLC-DAD) [15,44,45]. In this study, ultra-high-performance liquid chromatography with diode-array detection (UHPLC-DAD) has been used for its ability to separate compounds with high chromatographic resolution, due to the use of particles sizes smaller than $2 \mu \mathrm{m}$, which produces an increase in the working pressure and a shortening of the analysis times.

The present study intends to develop and optimize a methodology based on ultrasoundassisted for the extraction of anthocyanins from E. australis. The different variables involved in such method have been optimized based on a Box-Behnken design (BBD) combined with response surface methodology (RSM). The final aim of this study is to propose a novel extraction method of anthocyanins using UAE that allows to determine the anthocyanin content in Erica australis L. flower and other Erica species for different purposes.

\section{Materials and Methods}

\subsection{Biological Material}

Erica australis flowers (fresh) were collected in March 2019 from Los Barrios (Cadiz, Spain). The dry Erica australis, Erica arborea L. and Erica scoparia L. flowers were acquired from Zulueta Corporación (Tudela, Spain). All the samples were crushed with a ZM200 knife mill (Retsch $\mathrm{GmbH}$, Haan, Germany) and stored in a freezer at $-20{ }^{\circ} \mathrm{C}$ until further extraction.

\subsection{Chemical and Solvents}

Methanol (Fisher Chemical, Loughborough, UK) of HPLC grade and Milli-Q water, obtained from a Milli-Q water purification system (Millipore, Bedford, MA, USA) were selected as the extraction solvents. The liquid-liquid mixtures were carried out under the required percentage for each extraction and $\mathrm{pH}$ values were adjusted with $1 \mathrm{M}$ solutions prepared with $\mathrm{HCl}(37 \%$ - ACS reagent) and $\mathrm{NaOH}$ (99\%-ACS reagent) (Panreac, Barcelona, Spain).

For the chromatographic separation, methanol (Fisher Scientific, Waltham, MA, USA), and formic acid (Panreac, Barcelona, Spain) both HPLC grade were utilized.

Finally, cyanidin chloride ( $\geq 95 \%$ purity, Sigma-Aldrich Chemical Co., St. Louis, MO, USA) was employed as the commercial standard for the quantification of the extracted anthocyanins.

\subsection{Ultrasound-Assisted Extraction}

\subsubsection{Ultrasound-Assisted Extraction Equipment}

The ultrasound-assisted extraction equipment employed was a UP200S sonifier (200 W, $24 \mathrm{kHz}$ ) (Dr. Hielscher. GmbH, Berlin, Germany) with a water bath coupled to a temperature controller (FRIGITERM-10, J.P. Selecta, S.A., Barcelona, Spain).

\subsubsection{Ultrasound-Assisted Extraction Optimization}

Dry E. australis flowers were used for the UAE optimization based on a BDD with RSM. This design is one of the most widely used to optimize different processes, since it allows to determine the best values of the selected variables of interest, each variable's significance and the effects caused by the interactions between the selected variables. In order to generate this type of design, three variable values are selected per factor: $(-1)$ a lower level, (0) an intermediate level, and (1) a higher level. The design is characterized by lacking an embedded factorial or fractional factorial design and by not presenting any axial points. Instead, it generates a more spherical arrangement of the design points. Thanks to these characteristics, any experiment to be run under extreme or even unfeasible conditions that would cause a serious degradation of the samples or would imply unaffordable costs are excluded [46]. Four independents factors were selected to be investigated within the following ranges: composition of the extraction solvent $(\% \mathrm{MeOH}$ in water, with values from 0 to $50 \%$ ), extraction temperature (with values from 10 to $70{ }^{\circ} \mathrm{C}$ ), $\mathrm{pH}$ of the solvent (with 
values from 3 to 7 ), sample to solvent ratio (values from 10 to 20 (0.5 g:10 mL-0.5 g:20 mL)). The extraction time was set at $10 \mathrm{~min}$ for all experiments.

The percentage of $\mathrm{MeOH}$, the extraction temperature, and the solvent ratio were determined based on previous investigations carried out in the research group and bibliograpy $[32,35,36]$. Regarding the $\mathrm{pH}$ of the solvent, in aqueous solution, anthocyanins undergo structural re-arrangements in response to changes in $\mathrm{pH}$ in four molecular structures: quinoidal base (blue), flavylium cation (red), carbinol (colorless) and chalcone (yellowish) forms. Anthocyanins are stable in acidic solutions ( $\mathrm{pH} 1-3)$ where they exist primarily as flavylium cations. At $\mathrm{pH}>4$, anthocyanins adopt the forms of the carbinol and chalcone [47]. In previous studies, it has been shown that $\mathrm{pH}$ values close to 7 are capable of extracting a greater quantity of anthocyanins in hydroalcoholic mixtures $[19,21,38,48]$. $\mathrm{pH}$ values greater than 7 have not been tested, due to the instability of these compounds at basic $\mathrm{pH}$.

The BBD-RSM methodology was based on 27 extractions including three repetitions at the center point to determine the error. All the experiments were randomly performed. The response variable to be studied was the total relative area of the anthocyanins extracted from E. australis flowers samples under different conditions. This was calculated as the total sum of the areas corresponding to each one of the two major individual anthocyanins that had been previously identified. A summary of the experimental conditions according to the BBD-RSM and their results can be seen in Table 1.

Table 1. Box-Behnken design experiment for the optimization of total anthocyanins extraction from Erica australis flowers.

\begin{tabular}{|c|c|c|c|c|c|c|c|}
\hline Experiment & $\% \mathrm{MeOH}$ & $\begin{array}{c}\text { Temperature } \\
\left({ }^{\circ} \mathrm{C}\right)\end{array}$ & $\mathrm{pH}$ & Ratio (mL) & $\begin{array}{c}\text { Total } \\
\text { Anthocyanins } \\
\text { Measured } \\
\text { (Relative Area) }\end{array}$ & $\begin{array}{c}\text { Total } \\
\text { Anthocyanins } \\
\text { Predicted } \\
\text { (Relative Area) }\end{array}$ & $\begin{array}{c}\text { Relative } \\
\text { Error in the } \\
\text { Prediction } \\
(\%)\end{array}$ \\
\hline 1 & 25 & 10 & 5 & 10 & 337,455 & 389,145 & 15 \\
\hline 2 & 50 & 40 & 5 & 10 & 639,247 & 647,347 & 1 \\
\hline 3 & 50 & 40 & 5 & 20 & 757,508 & 775,737 & 2 \\
\hline 4 & 25 & 40 & 5 & 15 & 590,048 & 563,405 & 5 \\
\hline 5 & 25 & 70 & 5 & 10 & 573,794 & 551,805 & 4 \\
\hline 6 & 25 & 40 & 3 & 20 & 660,597 & 640,939 & 3 \\
\hline 7 & 25 & 40 & 7 & 10 & 505,854 & 494,633 & 2 \\
\hline 8 & 50 & 40 & 7 & 15 & 718,199 & 718,545 & 0 \\
\hline 9 & 50 & 10 & 5 & 15 & 725,040 & 648,277 & 11 \\
\hline 10 & 25 & 70 & 3 & 15 & 657,311 & 643,549 & 2 \\
\hline 11 & 25 & 40 & 7 & 20 & 616,314 & 608,983 & 1 \\
\hline 12 & 0 & 40 & 3 & 15 & 349,368 & 365,311 & 5 \\
\hline 13 & 25 & 70 & 7 & 15 & 603,419 & 621,473 & 3 \\
\hline 14 & 0 & 40 & 5 & 10 & 278,416 & 276,197 & 1 \\
\hline 15 & 0 & 70 & 5 & 15 & 411,697 & 457,587 & 11 \\
\hline 16 & 25 & 40 & 3 & 10 & 532,038 & 508,509 & 4 \\
\hline 17 & 25 & 10 & 3 & 15 & 461,176 & 458,929 & 0 \\
\hline 18 & 50 & 70 & 5 & 15 & 720,040 & 727,837 & 1 \\
\hline 19 & 25 & 10 & 5 & 20 & 451,491 & 489,735 & 8 \\
\hline 20 & 25 & 10 & 7 & 15 & 405,624 & 435,173 & 7 \\
\hline 21 & 0 & 40 & 7 & 15 & 348,784 & 320,695 & 8 \\
\hline 22 & 50 & 40 & 3 & 15 & 675,303 & 719,761 & 7 \\
\hline 23 & 0 & 10 & 5 & 15 & 204,944 & 166,227 & 19 \\
\hline 24 & 25 & 40 & 5 & 15 & 572,485 & 563,405 & 2 \\
\hline 25 & 25 & 40 & 5 & 15 & 527,052 & 563,405 & 7 \\
\hline 26 & 25 & 70 & 5 & 20 & 733,466 & 697,995 & 5 \\
\hline 27 & 0 & 40 & 5 & 20 & 386,912 & 394,587 & 2 \\
\hline
\end{tabular}

Once the extractions had been performed under the established experimental conditions, the resulting extracts were double centrifuged for $5 \mathrm{~min}$ at $7500 \mathrm{rpm}$ (orbital radius $9.5 \mathrm{~cm}$ ) and filtered using 0.20- $\mu \mathrm{m}$ nylon syringe filter (Membrane Solutions, Dallas, TX, USA) prior to their analysis for identification and/or quantification. 


\subsection{Identification of Anthocyanins by UHPLC-QToF-MS}

The anthocyanins present in the flower samples were identified by Ultra-Performance Liquid Chromatography coupled to a Photodiode Array-Quadrupole-Time-of-Flight Mass Spectrometer, (UHPLC-PDA-QToF-MS) (Xevo G2, Waters Corp., Milford, MA, USA). A $100 \times 2.1 \mathrm{~mm}$, particle size of $1.7 \mu \mathrm{m}$, reverse-phase C18 analytical column (Acquity UPLC BEH C18, Waters) was used. The solvent A employed for the analysis was formed by water containing $2 \%$ formic acid, whereas solvent $B$ was methanol with $2 \%$ formic acid. A $0.4 \mathrm{~mL} / \mathrm{min}$ flow rate was applied. The gradient followed for the identification was $5 \% \mathrm{~B}$ at $0 \mathrm{~min} ; 20 \% \mathrm{~B}$ at $3.30 \mathrm{~min} ; 30 \% \mathrm{~B}$ at $3.86 \mathrm{~min} ; 40 \% \mathrm{~B}$ at $5.05 \mathrm{~min} ; 55 \% \mathrm{~B}$ at $5.35 \mathrm{~min} ; 60 \% \mathrm{~B}$ at $5.64 \mathrm{~min} ; 95 \% \mathrm{~B}$ at $5.94 \mathrm{~min} ; 95 \% \mathrm{~B}$ at $7.50 \mathrm{~min}$. This represents 12 -min total analysis time, including the $4 \mathrm{~min}$ required for re-equilibration. The solution was ionized by means of an electrospray source in positive ionization mode and a desolvation gas flow of $700 \mathrm{~L} / \mathrm{h}$ at $500{ }^{\circ} \mathrm{C}$ and a capillary cone voltage of $700 \mathrm{~V}$. In addition, the cone gas flow was of $10 \mathrm{~L} / \mathrm{h}$ at $150{ }^{\circ} \mathrm{C}$ source temperature and $20 \mathrm{~V}$ with a trap collision energy of $4 \mathrm{eV}$. The full-scan mode was applied in the range $100-1200 \mathrm{~m} / z$.

Two major anthocyanins were identified in Erica australis L. flowers, as can be observed in Figure 1. Based on molecular ion $[\mathrm{M}]^{+}$, they were identified as cyanidin 3-O-glucoside $(m / z=449.1085)$ and peonidin 3-O-glucoside $(m / z=463.1242)$. The result are in agreement with previous characterization analyses on other Erica species, such as E. coccinea [45].

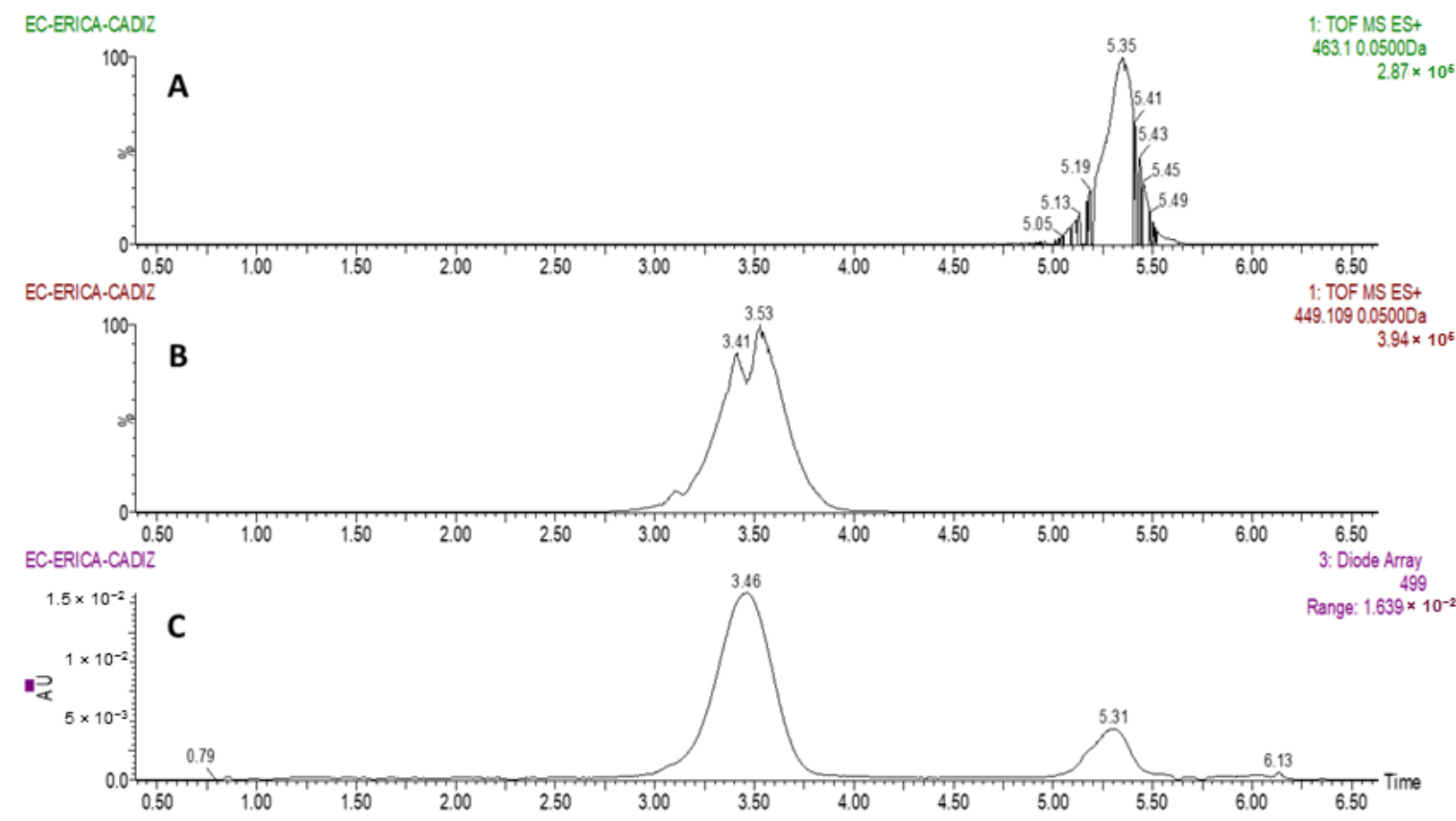

Figure 1. Chromatograms obtained from the analysis of Erica australis flowers by UHPLC-PDA-QToF-MS. (A): SIM chromatogram at $m / z 463.1$ (peonidin 3-O-glucoside); (B): SIM chromatogram at $m / z 449.1$ (cyanidin 3-O-glucoside); (C): UV-vis chromatogram at $\lambda 499 \mathrm{~nm}$ for anthocyanins.

\subsection{Analysis of Anthocyanins by UHPLC-UV-Vis}

Once the identification of anthocyanins was completed, UHPLC-UV-Vis was employed for quantification. An Elite UHPLC LaChrom System (Hitachi, Tokyo, Japan) system was used. The equipment comprised an L-2200U autosampler, an L2300 column oven set at $50{ }^{\circ} \mathrm{C}$, two L-2160U pumps, and a UV-Vis detector L-2420U. The analytical column used was a reversed-phase $2.1 \times 50 \mathrm{~mm}$ and $2.6 \mu \mathrm{m}$ particle size $\mathrm{C} 18$ (Phenomenex Kinetex, CoreShell Technology, Torrance, CA, USA). Two mobile phases were used as follows: acidified water ( $5 \%$ formic acid) as solvent $\mathrm{A}$ and methanol as solvent $\mathrm{B}$, operating 
at a constant flow rate of $0.7 \mathrm{~mL} / \mathrm{min}$. The gradient applied was: $15 \% \mathrm{~B}(0 \mathrm{~min}) ; 20 \%$ B (1.50 min); 30\% B (3.30 min); 40\% B (4.80 min); 55\% B (5.40 min); 60\% B (5.90 min); 95\% B (6.60 min); $95 \%$ B (9.30 min); 15\% B (10 min). Anthocyanins were measured at $520 \mathrm{~nm}$.

As it has been previously mentioned, cyanidin chloride was the standard selected for anthocyanins quantification according to the following calibration curve " $\mathrm{y}=300,568.88 \mathrm{x}-28462.43$ " and a determination coefficient of $\mathrm{R}^{2}=0.9999$.

The Shapiro-Wilk test was employed to evaluate the normal distribution of residuals, obtaining a $W$ value of 0.8514 (very close to 1 ) and a $p$-value of 0.803 (above 0.05 ), which confirms the normal distribution of the residuals.

The Limit of Detection (LOD) was $0.198 \mathrm{mg} / \mathrm{L}$ whereas the Limit of Quantification (LOQ) was $0.662 \mathrm{mg} / \mathrm{L}$ based on our previous studies [21]. The cyanidin chloride calibration curve was used to quantified the two major anthocyanins present in Erica australis L. flower extracts, assuming that the absorbance of the different anthocyanins were similar while taking into account their individual molecular weight. Each analysis was performed in triplicate.

\subsection{Optimization Study}

Once that the 27 extractions for the BBD-RSM were completed and the total anthocyanins content was determined, a second-order polynomial equation, where all the variables were considered, was applied as follows:

$\mathrm{Y}=\beta_{0}+\beta_{1} \mathrm{X}_{1}+\beta_{2} \mathrm{X}_{2}+\beta_{3} \mathrm{X}_{3}+\beta_{4} \mathrm{X}_{4}+\beta_{12} \mathrm{X}_{1} \mathrm{X}_{2}+\beta_{13} \mathrm{X}_{1} \mathrm{X}_{3}+\beta_{14} \mathrm{X}_{1} \mathrm{X}_{4}+\beta_{23} \mathrm{X}_{2} \mathrm{X}_{3}+\beta_{24} \mathrm{X}_{2} \mathrm{X}_{4}+\beta_{34} \mathrm{X}_{3} \mathrm{X}_{4}+\beta_{11} \mathrm{X}_{1}^{2}+\beta_{22} \mathrm{X}_{2}^{2}+\beta_{33} \mathrm{X}_{3}^{2}+\beta_{44} \mathrm{X}_{4}^{2}$

where $\mathrm{Y}$ is the aforesaid response, $\beta_{0}$ corresponds to the ordinate, $\mathrm{X}_{1}(\% \mathrm{MeOH}$ in the solvent), $X_{2}$ ( $\mathrm{pH}$ solvent), $X_{3}$ (extraction temperature), and $X_{4}$ (sample to solvent ratio) are the independent variables. Finally, $\beta_{\mathrm{i}}$ represents the linear coefficients; $\beta_{\mathrm{ij}}$ the cross-product coefficients, and $\beta_{\mathrm{ii}}$ indicates the quadratic coefficients.

Minitab v10.0 software (Minitab LLC, State College, PA, USA) was employed to perform the optimization analysis based on the effect of each variable on the final variable (total anthocyanins) according to a second-order mathematical model, the surface graphs, the calculation of the optimal levels of the significant variables and a variance analysis.

Lastly, once the variables' optimum values had been determined, repeatability and intermediate precision studies were carried out. For the repeatability analysis, nine extractions were conducted on the same day and for the intermediate precision study, four extractions were completed on each of three consecutive days (a total of twelve extractions). The coefficient of variation of the total relative areas of the anthocyanins was employed as the variable to determine the repeatability and intermediate precision of the developed method.

\subsection{Application of the Optimized Method}

Once the UAE methodology for the extraction of anthocyanins was optimized for Erica australis L. flowers, the developed method was applied to E. australis flowers (fresh) collected from Cadiz and to the flower samples from the other Erica species (E. arborea and E. scoparia-dry). The samples were extracted in triplicate under the established optimum conditions. The extracts were then centrifuged as previously described and analyzed by UHPLC-UV-vis.

\section{Results and Discussion}

\subsection{Optimization of the UAE Method}

The optimization of the UAE method was based on BBD-RSM according to four variables: composition of the extraction solvents, $\mathrm{pH}$ of the solvent, extraction temperature, and sample to solvent ratio. A BBD had been generated based on a total of 27 experiments (Table 1).

The flower samples were extracted under the required conditions and analyzed by UHPLC-UV-vis (520 nm) and two major anthocyanins were determined. The total antho- 
cyanins (the sum of the relative areas corresponding to each one of the two anthocyanins detected) was established as the response variable.

The real values and the values predicted by the BBD were correlated (Table 1) and an average $5 \%$ difference between the measured and predicted responses was obtained. The actual differences ranged between $0 \%$ and up to $19 \%$. The R-Squared statistic indicates that this model explained $96.21 \%$ of the recovery variability. The $p$-value for lack-of-fit in the ANOVA table (0.375) is greater than 0.05 , which means that the model is suitable for its intended purpose. Therefore, the model can be used to optimize the extraction conditions for the recovery of anthocyanins.

The BBD-RSM was then applied and the $p$-values were calculated according to the $t$-test using Minitab software at $95 \%$ confidence level, this means that the variables with $p$-values below 0.05 were considered as influential (Table 2).

Table 2. BBD-RSM analysis of the total anthocyanins recovery from Erica australis flowers.

\begin{tabular}{cccc}
\hline Variable & Sum of Squares & F-Value & $p$-Value \\
\hline$\% \mathrm{MeOH}$ & $4.24 \times 10^{11}$ & 216.04 & 0.000 \\
Temp & $1.03 \times 10^{11}$ & 52.72 & 0.000 \\
$\mathrm{pH}$ & $1.58 \times 10^{9}$ & 0.80 & 0.387 \\
Ratio & $4.56 \times 10^{10}$ & 23.23 & 0.000 \\
Temp $\times$ Temp & $6.94 \times 10^{9}$ & 3.54 & 0.180 \\
$\mathrm{pH} \times \mathrm{pH}$ & $3.98 \times 10^{9}$ & 2.03 & 0.849 \\
$\mathrm{Ratio} \times$ ratio & $7.44 \times 10^{7}$ & 0.04 & 0.843 \\
$\% \mathrm{MeOH} \times \mathrm{Temp}$ & $8.02 \times 10^{7}$ & 0.04 & 0.034 \\
$\% \mathrm{MeOH} \times \mathrm{pH}$ & $1.12 \times 10^{10}$ & 5.71 & 0.632 \\
$\% \mathrm{MeOH} \times$ ratio & $4.73 \times 10^{8}$ & 0.24 & 0.914 \\
Temp $\times$ pH & $2.38 \times 10^{7}$ & 0.01 & 0.985 \\
Temp $\times$ ratio & 688,900 & 0.00 & 0.616 \\
pH $\times$ ratio & $5.21 \times 10^{8}$ & 0.27 & 0.842 \\
\hline
\end{tabular}

The influence of each variable was graphically represented in a Pareto Chart (Figure 2) and as can be observed, the percentage of methanol in the solvent, the extraction temperature and the mass to solvent ratio have significant effects on the recovery of anthocyanins, in these cases with a positive influence in the total anthocyanins recovered. On the other hand, only one interaction presents a significant effect on the recovery of anthocyanins, which is the interaction between solvent composition $(\% \mathrm{MeOH})$ and extraction temperature ( $p$-value $=0.034)$, with a negative effect on the response variable.

The coefficients for each of the variables were obtained and replaced, generating the second order polynomial equation for the optimization of the extraction of anthocyanin in E. australis flowers:

$$
\begin{aligned}
\mathrm{Y}= & 563,195+187,935.0 \mathrm{X}_{1}+92,833.1 \mathrm{X}_{2}-11,466.6 \mathrm{X}_{3}+61,623.7 \mathrm{X}_{4}-52,938.2 \mathrm{X}_{1} \mathrm{X}_{2}+ \\
& 10,870.0 \mathrm{X}_{1} \mathrm{X}_{3}+2441.3 \mathrm{X}_{1} \mathrm{X}_{4}+415.0 \mathrm{X}_{2} \mathrm{X}_{3}+11,409.0 \mathrm{X}_{2} \mathrm{X}_{4}-4524.7 \mathrm{X}_{3} \mathrm{X}_{4}- \\
& 36,081.8 \mathrm{X}_{1}{ }^{2}-27,331.9 \mathrm{X}_{2}{ }^{2}+3734.3 \mathrm{X}_{3}{ }^{2}-3877.5 \mathrm{X}_{4}{ }^{2}
\end{aligned}
$$

Figure 3 shows the contour plots of the effect from $\% \mathrm{MeOH}$ vs. Temperature (Figure 3a.) and $\% \mathrm{MeOH}$ vs. ratio (Figure 3b.), where the interactions either between solvent composition and ratio or between solvent composition and extraction temperature are both more apparent when the methanol percentage in the extraction solvent is low. Therefore, the three extraction variables that affect the recovery of anthocyanins can be separately optimized. 


\section{Pareto Chart}

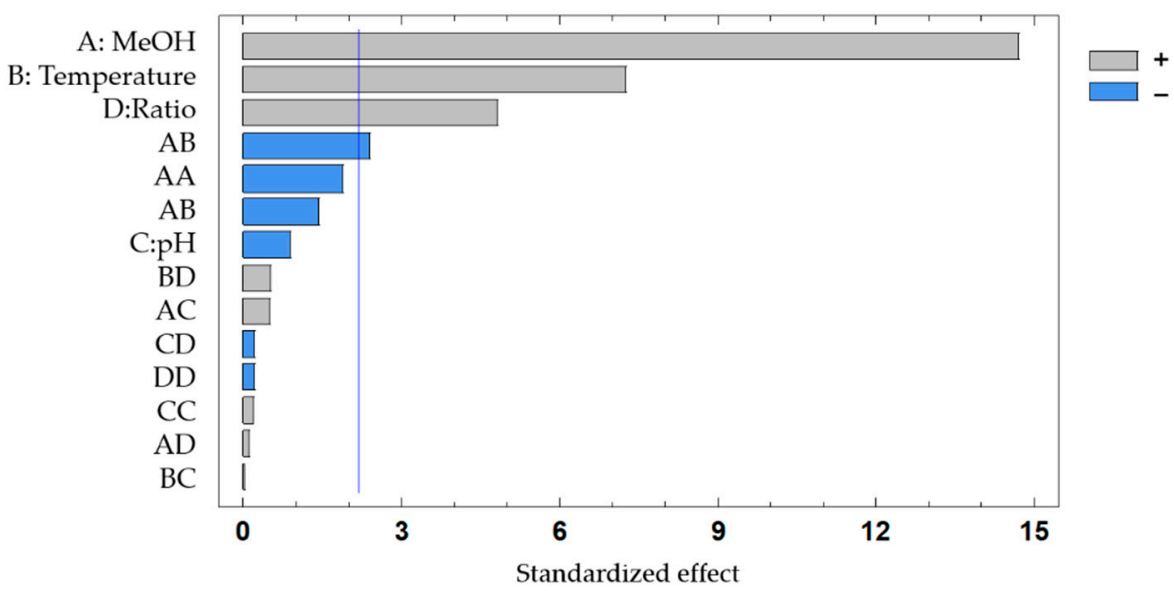

Figure 2. Standardized Pareto chart for the extraction of anthocyanins in Erica auntralis flowers $(p<0.05)$. A: \% $\mathrm{MeOH}$ in the solvent; B: Extraction temperature; $\mathrm{C}: \mathrm{pH}$ of the extraction solvent; D: Sample to solvent ratio.

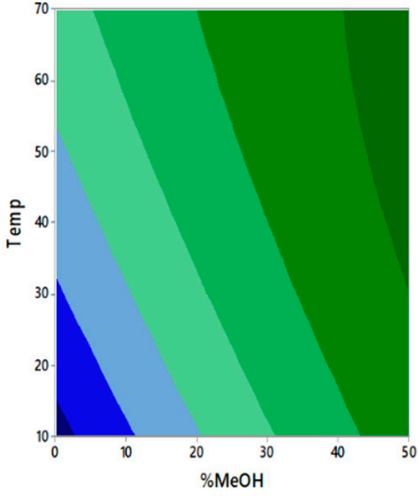

(a)
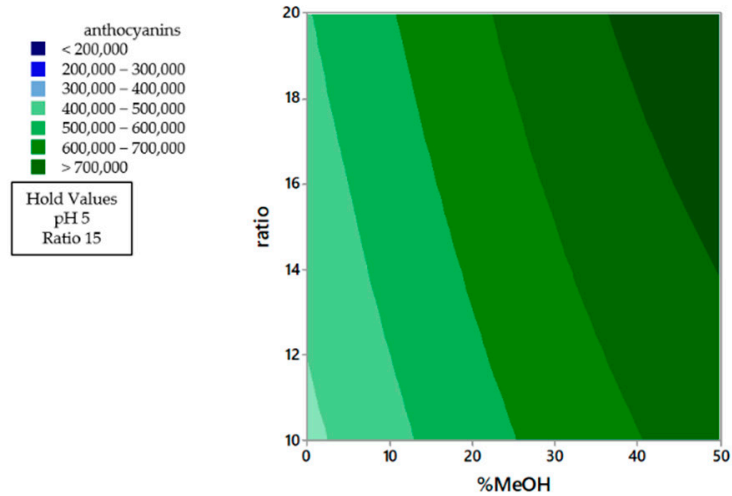

(b)

Figure 3. Contour plots of the effect from $\% \mathrm{MeOH}$ vs. temperature (a) and $\% \mathrm{MeOH}$ vs. ratio (b) on the recovery of anthocyanins.

The optimal extraction conditions obtained were $70{ }^{\circ} \mathrm{C}$ of temperature, $50 \% \mathrm{MeOH}$, $\mathrm{pH} 5$ and $20 \mathrm{~mL}$ of solvent per $0.5 \mathrm{~g}$ of sample. The ratio solvent to solid of the sample should not be increased, as the signal in the chromatographic system would be too low for a reliable determination. Similarly, the temperature should not be above $70{ }^{\circ} \mathrm{C}$ because the solvent would start boiling and this would affect the final recovery.

Some authors have observed that percentages of methanol near $70 \%$ were more optimal for the extraction of anthocyanins, especially from plant materials $[19,35,49]$. Finally, higher levels of methanol in the solvent were assayed while the rest of optimal extraction conditions according to the BBD were applied, i.e., $70^{\circ} \mathrm{C}, 20 \mathrm{~mL}$ of solvent per $0.5 \mathrm{~g}$ of sample and $\mathrm{pH}=5$. Figure 4 shows the recoveries obtained when using $50 \%, 60 \%, 70 \%, 80 \%, 90 \%$ and $100 \% \mathrm{MeOH}$ as the extracting solvent. It can be seen that for $\mathrm{MeOH}$ values between 50 and $90 \%$ the anthocyanins recoveries did not present any significant differences. On the contrary, when $100 \% \mathrm{MeOH}$ was employed, a lower recovery was achieved. 


\section{$1,200,000$}

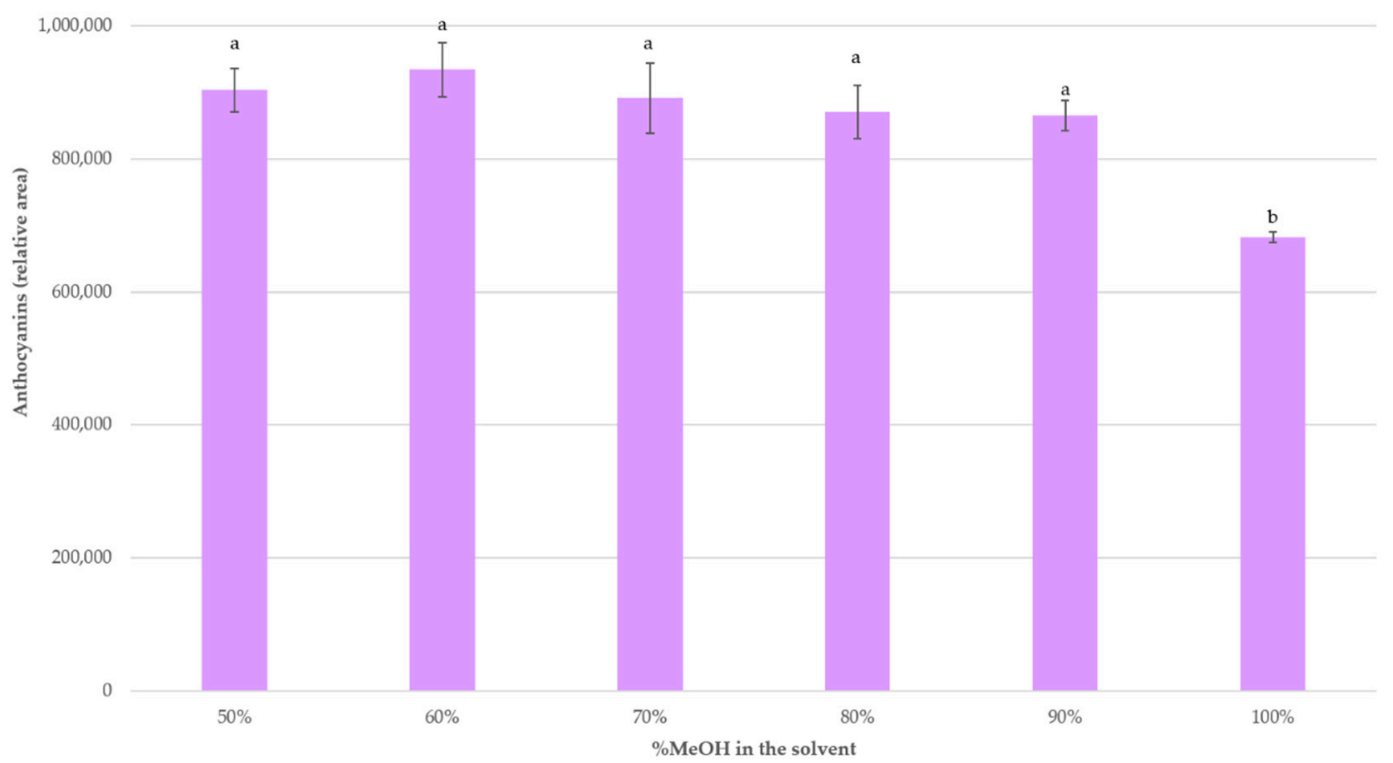

Figure 4. Average anthocyanins recoveries $(n=3)$ with different solvent percentages. A different letter over a bar indicates a significant difference $(p$-value $<0.05)$.

\subsection{Optimum Extraction Time}

Once the optimum conditions for the extraction of anthocyanins from E. australis flowers were determined, a kinetics study of the extraction process was conducted. For that purpose, $0.5 \mathrm{~g}$ samples were extracted under the established optimum conditions using different extraction times that ranged from 5 to $25 \mathrm{~min}$. The extractions were performed in triplicate for each extraction time. The average total anthocyanins extraction for each experimental time is displayed in Figure 5.

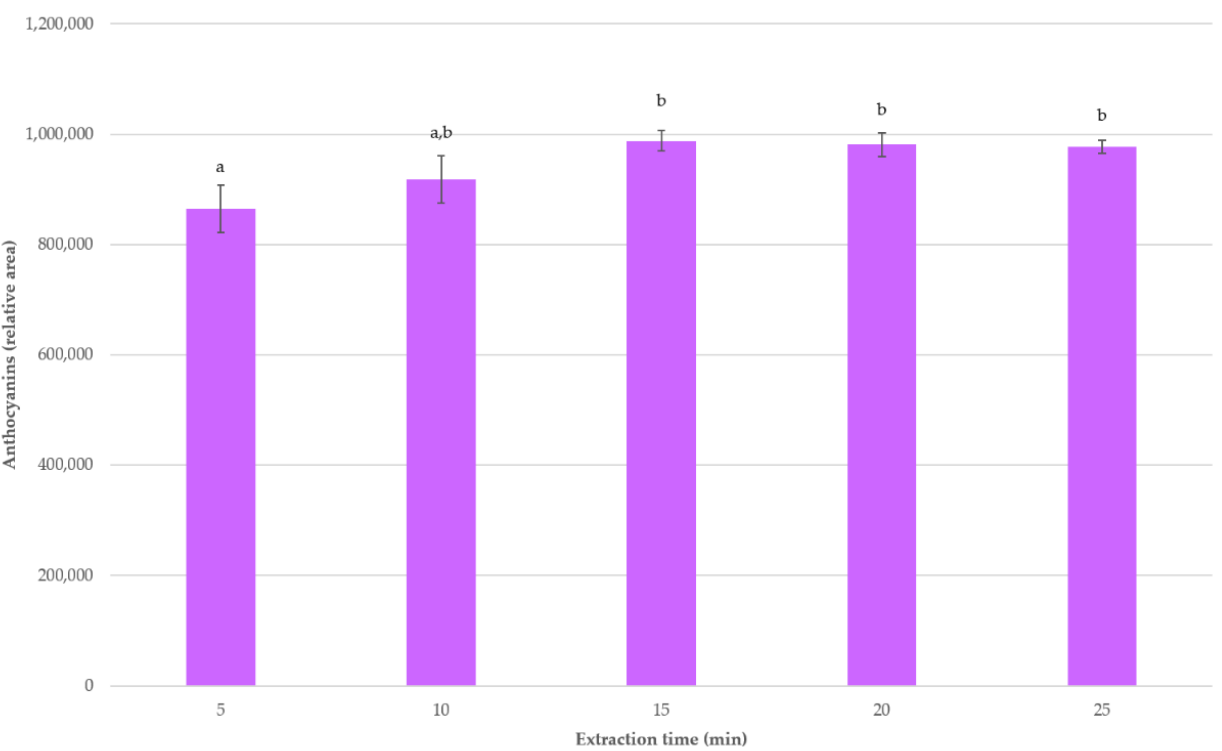

Figure 5. Average anthocyanins recoveries $(n=3)$ at different extraction times under the established UAE optimum conditions. A different letter over a bar indicates a significant difference ( $p$-value $<0.05)$. 
As it can be observed, the maximum amount of anthocyanins was extracted when the extraction time was $15 \mathrm{~min}$, with a noticeable difference in relation to the 5 min extractions and no significant differences with regard to any other of the extraction times. This fact is in agreement with the extraction time required for the extraction of anthocyanins from other matrices $[19,35,36]$. Moreover, no decreasing trend in anthocyanins recoveries was observed when longer extraction times (over $15 \mathrm{~min}$ ) were applied, which suggests that no anthocyanin degradation took place under such time conditions [50].

\subsection{Precision Study}

In order to determine the repeatability and intermediate precision of the optimized UAE method a number of extractions were performed under the optimum conditions $(0.5 \mathrm{~g}$ samples extracted with $20 \mathrm{~mL}$ of solvent $\left(50 \% \mathrm{MeOH}: \mathrm{H}_{2} \mathrm{O}\right)$ at $\mathrm{pH} 5$ for $15 \mathrm{~min}$ at $\left.70{ }^{\circ} \mathrm{C}\right)$.

For the repeatability study, 9 extractions were carried out on the same day. While for the intermediate precision study, 4 extractions were performed on each one of three consecutive days. All of the extractions were conducted according to the previously established optimum conditions. The average relative area and the residual relative standard deviation (RSD) have been summarize in Table 3.

Table 3. Precision study on anthocyanins UAE from Erica australis flowers.

\begin{tabular}{ccc}
\hline & Repeatability $^{\mathbf{1}}$ & Intermediate Precision $^{\mathbf{2}^{2}}$ \\
\hline Average & $966,332.07$ & $1,008,543.09$ \\
SD $^{*}$ & $32,003.30$ & $35,475.37$ \\
RSD $^{* *}$ & 3.31 & 3.52 \\
\hline
\end{tabular}

${ }^{1}$ Repeatability $(n=9) ;{ }^{2}$ Intermediate precision $(n=12) ;{ }^{*}$ Standard deviation; ${ }^{* *}$ Relative standard deviation.

The study results were all satisfactorily below 5\%, with $3.31 \%$ and $3.52 \%$ for intra-day and inter-day RSD respectively, which confirms a high precision level of the optimized UAE methodology for the extraction of anthocyanins from Erica flowers.

\subsection{Application of the Developed Method to Other Samples}

Lastly, the optimized method was applied to flower samples from three different Erica species comprising dry E. australis, E. arborea, and E. scoparia and fresh E. australis (from Cadiz). The total anthocyanins recoveries have been presented in Figure 6 and based on them, it can be affirmed that the UAE methodology that has been optimized in this study can be successfully and reliably applied to the extraction of anthocyanins from the flowers of the Erica genus.

Let us mention that significant differences in anthocyanins content were detected between the studied samples according to their origin or variety, where fresh E. australis flowers from the Cadiz area exhibited the largest anthocyanins recoveries reaching up to 0.22 (mg/g), followed by dry E. australis. Cyanidin 3-O-glucoside has been the majority anthocyanin in all the samples analyzed. In view of the results, the use of fresh Erica flowers is advised. 


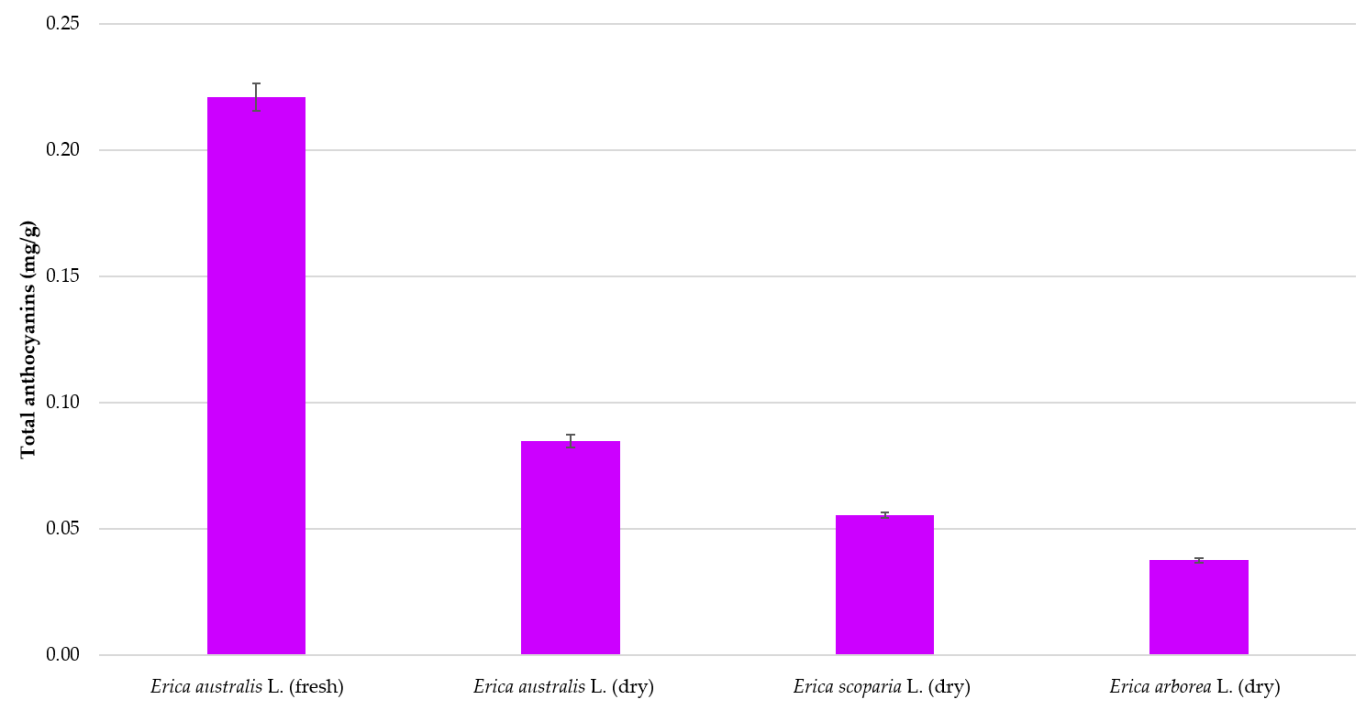

Figure 6. Total anthocyanins recovery from Erica genus flowers extracted under the established optimum conditions $(n=3)$.

\section{Conclusions}

In the present study, an ultrasound-assisted extraction methodology has been optimized to ensure the maximum recovery of anthocyanins from $E$. australis flowers. The percentage of methanol in the solvents, the extraction temperature, and the mass to solvent ratio have exhibited a significant influence on the total anthocyanins recoveries with $p$-values below 0.05 . In addition, the effect caused by the interaction between the solvent composition and the extraction temperature has similarly proven to be determinant for the extraction results.

The optimum conditions for the maximum anthocyanins extraction were established at $0.5 \mathrm{~g}$ samples extracted using $20 \mathrm{~mL}$ of solvent $\left(50 \% \mathrm{MeOH}: \mathrm{H}_{2} \mathrm{O}\right)$ with $\mathrm{pH} 5$ and at $70{ }^{\circ} \mathrm{C}$. Optimal extraction time was established at $15 \mathrm{~min}$, since maximum recoveries were achieved and no significant differences could be noticed when longer times, up to $25 \mathrm{~min}$, were used.

The repeatability and intermediate precision studies determined intra-day and interday RSD at $3.31 \%$ and $3.52 \%$ respectively, which confirms the satisfactory precision level of the optimized UAE methodology. Finally, the developed method has been applied to the dry flowers of three different Erica species (E. australis, E. arborea, and E. scoparia) and to the fresh flowers of Erica australis and its suitability for the extraction of anthocyanins from Erica matrices has been confirmed.

The results obtained in this study together with the well-known an numerous advantages associated to ultrasound-assisted methodologies, such as its rapid, uncomplicated and economic use and its scarce maintenance requirements, represent a substantial improvement in extraction techniques for numerous attractive matrices associated to health promoting properties or other uses such as those of E. australis flowers.

The authors consider the promising results obtained from this research to be a starting point for further research in a wide variety of fields. For example, the application of the UAE technique in the extraction of anthocyanins at an industrial level for the formation of enriched complexes or obtaining extracts that can be used in the food, pharmaceutical or cosmetic industry. In addition, these results lead to much more in-depth studies on the possible relationship between the bioactivity of anthocyanins and their bioavailability, as well as in the study of the content of anthocyanins in different Erica species, or the expression of anthocyanins in Erica species depending on the environmental conditions or external effects suffered by these plants. 
Author Contributions: Conceptualization, C.C., F.O.-C. and M.P.; methodology, F.O.-C. and C.C.; software, M.J.A.-G., M.F.-G. and G.F.B.; validation, G.F.B. and C.C.; formal analysis, C.C., J.R.-L. and M.J.A.-G.; investigation, F.O.-C. and C.C.; resources, M.P. and G.F.B.; data curation, C.C., M.P. and G.F.B.; writing-original draft preparation, C.C. and M.J.A.-G.; writing-review and editing, M.P., M.F.-G. and G.F.B.; visualization, G.F.B.; supervision, M.P., M.F.-G. and G.F.B.; project administration, G.F.B. and M.P.; funding acquisition, G.F.B. and M.P. All authors have read and agreed to the published version of the manuscript.

Funding: This work has been supported by the project "EQC2018-005135-P" (Equipment for liquid chromatography by means of mass spectrometry and ion chromatography) of the State Subprogram of Research Infrastructures and Technical Scientific Equipment.

Institutional Review Board Statement: Not applicable.

Informed Consent Statement: Not applicable.

Data Availability Statement: The data presented in this study is contained within the article.

Acknowledgments: The authors are grateful to the Instituto de Investigación Vitivinícola y Agroalimentaria (IVAGRO) for providing the necessary facilities to carry out the research. A special acknowledgement goes to Carmelo García Barroso (in memoriam) for his contribution to the scientific community in the area of phenolic compounds and oenology and his important inputs to this research.

Conflicts of Interest: The authors declare no conflict of interest.

Sample Availability: Samples of Erica flowers are available from the authors.

\section{References}

1. Gil-López, M.J.; Segarra-Moragues, J.G.; Désamoré, A.; Laenen, B.; Ojeda, F. Different Historical Backgrounds Determine Contrasting Phylogeographical Patterns in Two Co-Distributed Erica Species (Ericaceae) across the Strait of Gibraltar. Bot. J. Linn. Soc. 2017, 185, 359-375. [CrossRef]

2. Erica Australis Spanish Heath/RHS Gardening. Available online: https://www.rhs.org.uk/Plants/6599/Erica-australis/Details (accessed on 1 April 2021).

3. Valbuena, L.; Tárrega, R.; Luis-Calabuig, E. Seed Banks of Erica australis and Calluna vulgaris in a Heathland Subjected to Experimental Fire. J. Veg. Sci. 2000, 11, 161-166. [CrossRef]

4. Iglesia-Rodríguez, A. Efecto Del Fuego Sobre La Germinación y El Banco de Semillas Edáfico de Ericáceas de Galicia. Ph.D. Thesis, Santiago de Compostela University, Santiago de Compostela, Spain, 2010.

5. Cruz, A.; Moreno, J.M. No Allocation Trade-Offs between Flowering and Sprouting in the Lignotuberous, Mediterranean Shrub Erica Australis. Acta Oecol. 2001, 22, 121-127. [CrossRef]

6. Luís, Â.; Domingues, F.; Gil, C.; Duarte, A.P. Antioxidant Activity of Extracts of Portuguese Shrubs: Pterospartum tridentatum, Cytisus scoparius and Erica Spp. J. Med. Plants Res. 2009, 3, 886-893.

7. Akkol, E.K.; Yeşilada, E.; Güvenç, A. Valuation of Anti-Inflammatory and Antinociceptive Activities of Erica Species Native to Turkey. J. Ethnopharmacol. 2008, 116, 251-257. [CrossRef]

8. Nunes, R.; Anastácio, A.; Carvalho, I.S. Antioxidant and Free Radical Scavenging Activities of Different Plant Parts from Two Erica Species. J. Food Qual. 2012, 35, 307-314. [CrossRef]

9. Nunes, R.; Rodrigues, S.; Pasko, P.; Tyszka-Czochara, M.; Grenha, A.; de Carvalho, I.S. Effect of Erica australis Extract on Caco-2 Cells, Fibroblasts and Selected Pathogenic Bacteria Responsible for Wound Infection. Ind. Crop. Prod. 2014, 52, 99-104. [CrossRef]

10. Farzaneh, V.; Carvalho, I.S. A Review of the Health Benefit Potentials of Herbal Plant Infusions and Their Mechanism of Actions. Ind. Crop. Prod. 2015, 65, 247-258. [CrossRef]

11. Neves, J.M.; Matos, C.; Moutinho, C.; Queiroz, G.; Gomes, L.R. Ethnopharmacological Notes about Ancient Uses of Medicinal Plants in Trás-Os-Montes (Northern of Portugal). J. Ethnopharmacol. 2009, 124, 270-283. [CrossRef]

12. Harnafi, H.; Bouanani, N.e.H.; Aziz, M.; Serghini Caid, H.; Ghalim, N.; Amrani, S. The Hypolipidaemic Activity of Aqueous Erica Multiflora Flowers Extract in Triton WR-1339 Induced Hyperlipidaemic Rats: A Comparison with Fenofibrate. J. Ethnopharmacol. 2007, 109, 156-160. [CrossRef]

13. López-Hortas, L.; Conde, E.; Falqué, E.; Domínguez, H.; Torres, M.D. Antioxidant Capacity of the Extracts from Flowers of Erica australis L.: Comparison between Microwave Hydrodiffusion and Gravity (MHG) and Distillation Extraction TechniquesFormulation of Sunscreen Creams. Ind. Crop. Prod. 2020, 145, 112079. [CrossRef]

14. Márquez-García, B.; Fernández, M.Á.; Córdoba, F. Phenolics Composition in Erica Sp. Differentially Exposed to Metal Pollution in the Iberian Southwestern Pyritic Belt. Bioresour. Technol. 2009, 100, 446-451. [CrossRef]

15. Nunes, R.; Carvalho, I.S. Antioxidant Activities, Distribution of Phenolics and Free Amino Acids of Erica australis L. Leaves and Flowers Collected in Algarve, Portugal. Nat. Prod. Res. 2013, 27, 1664-1667. [CrossRef] 
16. Márquez-García, B.; Córdoba, F. Antioxidative System and Oxidative Stress Markers in Wild Populations of Erica australis L. Differentially Exposed to Pyrite Mining Activities. Environ. Res. 2009, 109, 968-974. [CrossRef]

17. Fallah, A.A.; Sarmast, E.; Jafari, T. Effect of Dietary Anthocyanins on Biomarkers of Oxidative Stress and Antioxidative Capacity: A Systematic Review and Meta-Analysis of Randomized Controlled Trials. J. Funct. Food. 2020, 68, 103912. [CrossRef]

18. Belwal, T.; Singh, G.; Jeandet, P.; Pandey, A.; Giri, L.; Ramola, S.; Bhatt, I.D.; Venskutonis, P.R.; Georgiev, M.I.; Clément, C.; et al. Anthocyanins, Multi-Functional Natural Products of Industrial Relevance: Recent Biotechnological Advances. Biotechnol. Adv. 2020, 43, 107600. [CrossRef] [PubMed]

19. González-de-Peredo, A.V.; Vázquez-Espinosa, M.; Espada-Bellido, E.; Ferreiro-González, M.; Carrera, C.; Palma, M.; Álvarez, J.Á.; Barbero, G.F.; Ayuso, J. Optimization of Analytical Ultrasound-Assisted Methods for the Extraction of Total Phenolic Compounds and Anthocyanins from Sloes (Prunus Spinosa L.). Agronomy 2020, 10, 966. [CrossRef]

20. González-de-Peredo, A.V.; Vázquez-Espinosa, M.; Espada-Bellido, E.; Ferreiro-González, M.; Amores-Arrocha, A.; Palma, M.; Barbero, G.F.; Jiménez-Cantizano, A. Discrimination of Myrtle Ecotypes from Different Geographic Areas According to Their Morphological Characteristics and Anthocyanins Composition. Plants 2019, 8, 328. [CrossRef] [PubMed]

21. Aliaño-González, M.J.; Ferreiro-González, M.; Espada-Bellido, E.; Carrera, C.; Palma, M.; Álvarez, J.A.; Ayuso, J.; Barbero, G.F. Extraction of Anthocyanins and Total Phenolic Compounds from Açai (Euterpe Oleracea Mart.) Using an Experimental Design Methodology. Part 1: Pressurized Liquid Extraction. Agronomy 2020, 10, 183. [CrossRef]

22. Aliaño-González, M.J.; Jarillo, J.A.; Carrera, C.; Ferreiro-González, M.; Álvarez, J.Á.; Palma, M.; Ayuso, J.; Barbero, G.F.; EspadaBellido, E. Optimization of a Novel Method Based on Ultrasound-Assisted Extraction for the Quantification of Anthocyanins and Total Phenolic Compounds in Blueberry Samples (Vaccinium Corymbosum L.). Foods 2020, 9, 1763. [CrossRef]

23. Tarapatskyy, M.; Kapusta, I.; Gumienna, A.; Puchalski, C. Assessment of the Bioactive Compounds in White and Red Wines Enriched with a Primula veris L. Molecules 2019, 24, 4074. [CrossRef] [PubMed]

24. Zhou, C.; Mei, X.; Rothenberg, D.O.; Yang, Z.; Zhang, W.; Wan, S.; Yang, H.; Zhang, L. Metabolome and Transcriptome Analysis Reveals Putative Genes Involved in Anthocyanin Accumulation and Coloration in White and Pink Tea (Camellia sinensis) Flower. Molecules 2020, 25, 190. [CrossRef] [PubMed]

25. Fang, J. Classification of Fruits Based on Anthocyanin Types and Relevance to Their Health Effects. Nutrition 2015, 31, 1301-1306. [CrossRef] [PubMed]

26. Cassidy, A. Berry Anthocyanin Intake and Cardiovascular Health. Mol. Asp. Med. 2018, 61, 76-82. [CrossRef] [PubMed]

27. Jokioja, J.; Linderborg, K.M.; Kortesniemi, M.; Nuora, A.; Heinonen, J.; Sainio, T.; Viitanen, M.; Kallio, H.; Yang, B. AnthocyaninRich Extract from Purple Potatoes Decreases Postprandial Glycemic Response and Affects Inflammation Markers in Healthy Men. Food Chem. 2020, 310, 125797. [CrossRef] [PubMed]

28. Han, Y.; Guo, Y.; Cui, S.W.; Li, H.; Shan, Y.; Wang, H. Purple Sweet Potato Extract Extends Lifespan by Activating Autophagy Pathway in Male Drosophila melanogaster. Exp. Gerontol. 2021, 144, 111190. [CrossRef]

29. Medina-Torres, N.; Ayora-Talavera, T.; Espinosa-Andrews, H.; Sánchez-Contreras, A.; Pacheco, N. Ultrasound Assisted Extraction for the Recovery of Phenolic Compounds from Vegetable Sources. Agronomy 2017, 7, 47. [CrossRef]

30. Ciulu, M.; Cádiz-Gurrea, M.; Segura-Carretero, A. Extraction and Analysis of Phenolic Compounds in Rice: A Review. Molecules 2018, 23, 2890. [CrossRef]

31. Al-Suod, H.; Ratiu, I.A.; Krakowska-Sieprawska, A.; Lahuta, L.; Górecki, R.; Buszewski, B. Supercritical Fluid Extraction in Isolation of Cyclitols and Sugars from Chamomile Flowers. J. Sep. Sci. 2019, 42, 3243-3252. [CrossRef] [PubMed]

32. Al-Suod, H.; Ratiu, I.A.; Górecki, R.; Buszewski, B. Pressurized Liquid Extraction of Cyclitols and Sugars: Optimization of Extraction Parameters and Selective Separation. J. Sep. Sci. 2019, 42, 1265-1272. [CrossRef]

33. Baiano, A. Recovery of Biomolecules from Food Wastes-A Review. Molecules 2014, 19, 14821-14842. [CrossRef]

34. González-de-Peredo, A.V.; Vázquez-Espinosa, M.; Espada-Bellido, E.; Carrera, C.; Ferreiro-González, M.; Barbero, G.F.; Palma, M. Flavonol Composition and Antioxidant Activity of Onions (Allium cepa L.) Based on the Development of New Analytical Ultrasound-Assisted Extraction Methods. Antioxidants 2021, 10, 273. [CrossRef] [PubMed]

35. Aourach, M.; González-de-Peredo, A.V.; Vázquez-Espinosa, M.; Essalmani, H.; Palma, M.; Barbero, G.F. Optimization and Comparison of Ultrasound and Microwave-Assisted Extraction of Phenolic Compounds from Cotton-Lavender (Santolina chamaecyparissus L.). Agronomy 2021, 11, 84. [CrossRef]

36. Espada-Bellido, E.; Ferreiro-González, M.; Carrera, C.; Palma, M.; Álvarez, J.A.; Barbero, G.F.; Ayuso, J. Extraction of Antioxidants from Blackberry (Rubus ulmifolius L.): Comparison between Ultrasound- and Microwave-Assisted Extraction Techniques. Agronomy 2019, 9, 745. [CrossRef]

37. Vázquez-Espinosa, M.; González de Peredo, A.V.; Ferreiro-González, M.; Barroso, C.G.; Palma, M.; Barbero, G.F.; Espada-Bellido, E. Optimizing and Comparing Ultrasound- and Microwave-Assisted Extraction Methods Applied to the Extraction of Antioxidant Capsinoids in Peppers. Agronomy 2019, 9, 633. [CrossRef]

38. Aliaño-González, M.J.; Espada-Bellido, E.; Ferreiro-González, M.; Carrera, C.; Palma, M.; Ayuso, J.; Álvarez, J.Á.; Barbero, G.F. Extraction of Anthocyanins and Total Phenolic Compounds from Açai (Euterpe oleracea Mart.) Using an Experimental Design Methodology. Part 2: Ultrasound-Assisted Extraction. Agronomy 2020, 10, 326. [CrossRef]

39. Zhu, Z.; Jiang, T.; He, J.; Barba, F.; Cravotto, G.; Koubaa, M. Ultrasound-Assisted Extraction, Centrifugation and Ultrafiltration: Multistage Process for Polyphenol Recovery from Purple Sweet Potatoes. Molecules 2016, 21, 1584. [CrossRef] 
40. Gullian Klanian, M.; Terrats Preciat, M. Optimization of the Ultrasound-Assisted Extraction of Phenolic Compounds from Brosimum alicastrum Leaves and the Evaluation of Their Radical-Scavenging Activity. Molecules 2017, 22, 1286. [CrossRef]

41. Leichtweis, M.G.; Pereira, C.; Prieto, M.A.; Barreiro, M.F.; Barros, L.; Ferreira, I.C.F.R. Ultrasound as a Rapid and Low-Cost Extraction Procedure to Obtain Anthocyanin-Based Colorants from Prunus spinosa L. Fruit Epicarp: Comparative Study with Conventional Heat-Based Extraction. Molecules 2019, 24, 573. [CrossRef]

42. Bamba, B.; Shi, J.; Tranchant, C.; Xue, S.; Forney, C.; Lim, L.-T. Influence of Extraction Conditions on Ultrasound-Assisted Recovery of Bioactive Phenolics from Blueberry Pomace and Their Antioxidant Activity. Molecules 2018, 23, 1685. [CrossRef] [PubMed]

43. Paladines-Quezada, D.F.; Fernández-Fernández, J.I.; Moreno-Olivares, J.D.; Bleda-Sánchez, J.A.; Gómez-Martínez, J.C.; MartínezJiménez, J.A.; Gil-Muñoz, R. Application of Elicitors in Two Ripening Periods of Vitis vinifera L. cv Monastrell: Influence on Anthocyanin Concentration of Grapes and Wines. Molecules 2021, 26, 1689. [CrossRef]

44. Veličković, V.; Đurović, S.; Radojković, M.; Cvetanović, A.; Švarc-Gajić, J.; Vujić, J.; Trifunović, S.; Mašković, P.Z. Application of Conventional and Non-Conventional Extraction Approaches for Extraction of Erica carnea L.: Chemical Profile and Biological Activity of Obtained Extracts. J. Supercrit. Fluids 2017, 128, 331-337. [CrossRef]

45. Ojeda, F.; Midgley, J.; Pauw, A.; Lavola, A.; Casimiro-Soriguer, R.; Hattas, D.; Segarra-Moragues, J.G.; Julkunen-Tiitto, R. Flower Colour Divergence Is Associated with Post-Fire Regeneration Dimorphism in the Fynbos Heath Erica coccinea Subsp. Coccinea (Ericaceae). Evol. Ecol. 2019, 33, 345-367. [CrossRef]

46. Prakash Maran, J.; Manikandan, S.; Thirugnanasambandham, K.; Vigna Nivetha, C.; Dinesh, R. Box-Behnken Design Based Statistical Modeling for Ultrasound-Assisted Extraction of Corn Silk Polysaccharide. Carbohydr. Polym. 2013, 92, 604-611. [CrossRef]

47. Kamiloglu, S.; Capanoglu, E.; Grootaert, C.; van Camp, J. Anthocyanin Absorption and Metabolism by Human Intestinal Caco-2 Cells-A Review. Int. J. Mol. Sci. 2015, 16, 21555-21574. [CrossRef] [PubMed]

48. González de Peredo, A.V.; Vázquez-Espinosa, M.; Espada-Bellido, E.; Ferreiro-González, M.; Amores-Arrocha, A.; Palma, M.; Barbero, G.F.; Jiménez-Cantizano, A. Alternative Ultrasound-Assisted Method for the Extraction of the Bioactive Compounds Present in Myrtle (Myrtus communis L.). Molecules 2019, 24, 882. [CrossRef]

49. Mariychuk, R.; Eliasova, A.; Porubska, J.; Poracova, J.; Simko, V. Isolation and Lyophilisation of Anthocyanins from Fruits of Blackcurrant. Acta Hortic. 2016, 1133, 329-333. [CrossRef]

50. Kumar, M.; Dahuja, A.; Sachdev, A.; Kaur, C.; Varghese, E.; Saha, S.; Sairam, K.V.S.S. Valorisation of Black Carrot Pomace: Microwave Assisted Extraction of Bioactive Phytoceuticals and Antioxidant Activity Using Box-Behnken Design. J. Food Sci. Technol. 2019, 56, 995-1007. [CrossRef] 